Article

\title{
Pellets from Lignocellulosic Material Obtained from Pruning Guava Trees: Characterization, Energy Performance and Emissions
}

\author{
Víctor Manuel Ruiz-García ${ }^{1,2}$, Maritza Yunuen Huerta-Mendez ${ }^{3}$, Juan Carlos Vázquez-Tinoco ${ }^{1}$, \\ José Juan Alvarado-Flores ${ }^{3}$, Víctor Manuel Berrueta-Soriano ${ }^{4}$, Pablo López-Albarrán ${ }^{3} \mathbb{C}$, Omar Masera ${ }^{1}$ \\ and José Guadalupe Rutiaga-Quiñones ${ }^{3, *}$
}

check for updates

Citation: Ruiz-García, V.M.; Huerta-Mendez, M.Y; VázquezTinoco, J.C.; Alvarado-Flores, J.J.; Berrueta-Soriano, V.M.; LópezAlbarrán, P.; Masera, O.; RutiagaQuiñones, J.G. Pellets from Lignocellulosic Material Obtained from Pruning Guava Trees:

Characterization, Energy Performance and Emissions. Sustainability 2022, 14, 1336. https://doi.org/10.3390/ su14031336

Academic Editor: Jorge Aburto

Received: 19 December 2021

Accepted: 21 January 2022

Published: 25 January 2022

Publisher's Note: MDPI stays neutral with regard to jurisdictional claims in published maps and institutional affiliations.

Copyright: (C) 2022 by the authors. Licensee MDPI, Basel, Switzerland. This article is an open access article distributed under the terms and conditions of the Creative Commons Attribution (CC BY) license (https:// creativecommons.org/licenses/by/ $4.0 /)$.
1 Instituto de Investigaciones en Ecosistemas y Sustentabilidad (IIES), Universidad Nacional Autónoma de México (UNAM), Morelia C.P. 58190, Mexico; vruiz@cieco.unam.mx (V.M.R.-G.); lineb@cieco.unam.mx (J.C.V.-T.); omasera@cieco.unam.mx (O.M.)

2 Consejo Nacional de Ciencia y Tecnología (CONACYT), Ciudad de México C.P. 03940, Mexico

3 Facultad de Ingeniería en Tecnología de la Madera (FITECMA), Universidad Michoacana de San Nicolás de Hidalgo (UMSNH), Morelia C.P. 58040, Mexico; 0670356c@umich.mx (M.Y.H.-M.); jjalvarado@umich.mx (J.J.A.-F.); plopez@umich.mx (P.L.-A.)

4 Grupo Interdisciplinario de Tecnología Rural Apropiada, A.C. (GIRA, A.C.), Pátzcuaro C.P. 61613, Mexico; vberrueta@gira.org.mx

* Correspondence: rutiaga@umich.mx

\begin{abstract}
In this study, lignocellulosic material derived from guava tree pruning was used to make pellets in a laboratory machine. The following experiments were conducted to identify the properties of the biomass samples before the pelletizing process: chemical analysis, proximal analysis, elemental analysis, ash microanalysis and thermogravimetric analysis (TGA-DTG). The following analyses were performed on the densified material: moisture content, particle density, bulk density, impact resistance and calorific value. The guava pellets evaluated, with respect to open fires, mitigate the $\mathrm{CO}_{2}, \mathrm{CO}, \mathrm{CH}_{4}, \mathrm{HCNM}, \mathrm{EC}, \mathrm{OC}$ and $\mathrm{PM}_{2.5}$ emissions. Emissions per unit of consumed energy were reduced by 8 times for $\mathrm{PM}_{2.5}$, almost 5 times for $\mathrm{HCNM}, 3$ times for $\mathrm{CH}_{4}, 7$ times for $\mathrm{CO}, 2$ times for $\mathrm{CO}_{2}, 6$ times with respect to $\mathrm{EC}$ and almost 30 times for $\mathrm{OC}$. The results of the physical and energetic evaluation of the pellets indicate good potential for its use as a solid densified biofuel.
\end{abstract}

Keywords: Psidium guajava; lignocellulosic material; greenhouse gases; particulate matter; organic and elemental carbon

\section{Introduction}

The high dependence on fossil fuels that produce greenhouse gases and other pollutants [1], as well as social and environmental degradation in our societies, are evidence of the need for an energy revolution or energy democracy [2,3]. It is therefore urgent to carry out a transition to clean and renewable energy sources, which are capable of satisfying worldwide energy demands and allow us to achieve a sustainable future $[4,5]$. Investing in alternative sources of renewable energy can help solve this problem [6-8]. It is known that alternative energy sources include solar, tidal, wave, wind, hydraulic, geothermal, hydrogen and biomass [9-11]. The Mexican energy system is $86.4 \%$ dependent on fossil fuels (oil 62.4\%, natural gas 19.7\%, and $4.3 \%$ coal) and the contribution of renewable energies is only $10.4 \%$ (hydroenergy $1.5 \%$, biomass (firewood and sugarcane bagasse) $5.7 \%$, geoenergy (solar and wind) $2.8 \%$, and biogas $0.1 \%$ ) [12]. With this scenario, Mexico faces a great challenge to move towards the transition from renewable energy sources [1]. Solid biofuels (wood chips, firewood, briquettes, pellets, and charcoal) are considered to be important energy vectors derived from biomass [13].

Biomass for energy use comes from two sources: energy crops (herbaceous and woody) and remains and residues (agricultural crops, forestry operations, agri-food industries, 
forestry industries, livestock operations, marine products or remains, and human activities) [10]. The remains of woody agricultural crops include pruning or the elimination of fruit plantations, such as olive, citrus, vine [10], guava, among others. Mexico ranks 5th in worldwide guava production [14]. Twenty states of the republic are producers of this fruit, with an area of 22,562 ha [15], with the state of Michoacán being the one with the highest production, with a volume of 179,133 tons in 2019 , which represents $58.2 \%$ of the national production [16]. To control the production of this fruit, water stress, defoliation and pruning work can be carried out, with pruning being the most common practice [16]. In Mexico, it is estimated that a guava tree produces approximately $9 \mathrm{~kg}$ of foliar biomass per year [16] and orchards have a density of 154 to 666 trees per hectare [17], therefore, the country could generate 1386 to $5994 \mathrm{~kg}$ of foliar biomass per hectare per year. The foliage of the guava tree has been studied in relation to its chemical composition; antioxidant, antifungal and antibacterial properties; and in medicinal treatments [18-22]. On the other hand, in Mexico, it is estimated that pruning generates approximately $12 \mathrm{~kg}$ of biomass per tree per year (1848 to $7992 \mathrm{~kg}$ per hectare per year) and these lignocellulosic residues are usually not used and are left in guava orchards. In relation to this biomass, there are few studies that have reported on its chemical composition [21,23-25], and the evaluation of physical and mechanical properties to develop truss prototypes [26]. Results have recently been reported on the physical and chemical properties of briquettes made with guava pruning residues in Ecuador [27]. The aim of this study is to develop pellets with pruning residues and to evaluate their physical, chemical and thermal properties, based in part on thermogravimetric (TGA) and differential (DTG) analysis, in order to visualize the main zones of characteristic degradation and temperatures and percentage quantities in each zone, in addition to evaluating greenhouse gases with the aim of identifying their energy potential as a solid densified biofuel.

\section{Materials and Methods}

\subsection{Collection and Availability of Biomass}

The biomass extraction was carried out in the Community of Tomendan, municipality of Tarétan, in the state of Michoacán, Mexico, which has an area of 1407 ha, of which 599,350 ha correspond to plantations with Psidium guajava trees. In each hectare, there are 400 guava trees $(239,740$ trees in total) and approximately $12 \mathrm{~kg}$ of biomass are subtracted per tree, which is equivalent to 2876.88 tons of biomass available per year. From an orchard belonging to the El Cobano ejido, 20 trees were randomly chosen with an age of 15 years and a height of approximately $3 \mathrm{~m}$.

On average, $12.3 \mathrm{~kg}$ of pruning material were collected per tree (branches without leaves) and in total there were $246 \mathrm{~kg}$ of biomass available for this study. In order to determine the local use of the biomass generated in the pruning, a survey was conducted with 33 people belonging to the El Cobano ejido. The objective of the survey questions was to identify the final destination of this biomass.

\subsection{Material Preparation}

Samples were taken from the pruning material to determine the initial moisture content [28] and the rest was reduced to small pieces of approximately $10 \mathrm{~cm}$ and allowed to dry in the open air. Subsequently, a sample of this material was ground in Micron equipment (Micron, model K20F, Mexico City, Mexico) and sieved in ROTAP equipment (Tayler, RX-29, Mentor, OH, USA), to finally obtain 40 mesh $(425 \mu \mathrm{m})$ woodmeal, which was used for chemical analysis. The rest of the biomass was ground on a knife and the obtained material was used to make the pellets.

\subsection{Physical and Chemical Characterization of Biomass}

The moisture content of the material obtained from the dry pruning in the open air was determined in triplicate. Moisture content was determined by placing a petri dish of $1 \mathrm{~g}$ samples of pellets from each source in an oven for $4 \mathrm{~h}$ at $105 \pm 2{ }^{\circ} \mathrm{C}$, the values were 
calculated according to the EN ISO 18134-3 [28]. Lignin and polysaccharide content was obtained utilizing an ANAKOM-200 fiber analyzer (NY, USA), using $\alpha$-amylase [29]. The proportion of extractives was calculated by difference and correction of the ash content was applied. This analysis was performed once. For the proximate analysis, the ash content was determined according to the EN ISO 18,122 [30] standard and the volatile material based on the EN ISO 18,123 [31] standard. Ash content was determined placing $1 \mathrm{~g}$ of test samples in a muffle at $250{ }^{\circ} \mathrm{C}$ for $1 \mathrm{~h}$, after which the temperature was increased up to $550{ }^{\circ} \mathrm{C}$ and remained at this condition for $2 \mathrm{~h}$. Volatile material was determined after heating in a muffle at $900 \pm 10{ }^{\circ} \mathrm{C}$ for $7 \mathrm{~min}$. Then, $1 \mathrm{~g}$ samples of pellets were analyzed. Fixed carbon was calculated by difference, subtracting the ash and volatile content from 100 . These analyses were carried out in triplicate. The carbon, hydrogen, nitrogen and sulfur content was determined in duplicate on an elemental analyzer (Thermo Scientific, Flash 2000, Waltham, MA, USA) using the Dumas method [32]. Oxygen was calculated by difference. The ash microanalysis was determined according to the methodology proposed by Arcibar-Orozco et al. [33], by inductively coupling plasma atomic emission spectrophotometer (ICP-AES) on a Varian spectrometer (Model 730-ES, Varian Inc. (Aligent), Mulgrave, Australia). This analysis was carried out only once and, by means of this methodology, the presence of 29 chemical elements was identified.

\subsection{Thermogravimetric Analysis}

The thermal analysis (TGA-DTG) of the lignocellulosic material obtained from the pruning of guava trees was carried out on a STA 6000 (Perkin Elmer Inc., Wellesley, Waltham, MA, USA). The pyrolytic conditions were maintained using reagent grade nitrogen gas (99.99\% purity; INFRA, Mexico City, Mexico). The nitrogen flow was kept at $20 \mathrm{~mL} / \mathrm{min}$. Approximately $30 \pm 5 \mathrm{mg}$ of 40 mesh $(425 \mu \mathrm{m})$ sample was uniformly placed in an alumina crucible for each test. The samples were heated from 25 to $900{ }^{\circ} \mathrm{C}$ at a heating rate of $20^{\circ} \mathrm{C} / \mathrm{min}$. The software used for the thermal analysis was OriginPro-Graphing \& Analiysis. Each test was performed in duplicate. The heating ramps were performed in triplicate only when the conversion difference was greater than $5 \%$ or the data had a lot of background noise.

\subsection{Manufacture and Characterization of Pellets}

This densified material was obtained on a laboratory pelletizer (Meelko Co., Type ZLSP200C, Opa Locka, FL, USA) with a production capacity of 80 to $120 \mathrm{~kg} / \mathrm{h}$. Approximately $20 \mathrm{~kg}$ of pellets were obtained. The particle size of the biomass used in the pelletizing process was less than $4 \mathrm{~mm}$. The selection of the particle size was carried out in an ROTAP. To identify the moisture content of the guava pellets obtained in the pelletizing equipment, the EN ISO 18134-3 [28] standard was used and was carried out in triplicate. The particle density was determined by dividing the mass by the volume, using a sample of twenty pellets. On the other hand, the bulk density of the guava pellets was calculated following the UNE-EN 15,103 [34] standard. The impact resistance of the pellets was determined according to the methodology proposed by Richards [35] and the retention percentage was determined by dividing the weight of the total number of pieces of pellets produced after four falls between the initial weight of the pellets and multiplying the result by 100 . The higher calorific value of the guava pellets was determined in triplicate according to the UNE-EN 14,918 [36] standard, using a Parr calorimeter (Parr model 6100, Moline, IL, USA). The calorimeter injects pure oxygen (99.5\%) at $350 \mathrm{psi}$ and uses benzoic acid as the standard. The energy density was obtained by multiplying the average calorific value of the pellets by their average bulk density.

\subsection{Energy Performance and Greenhouse Gases Produced by the Combustion of Pellets}

To evaluate the performance of the guava tree pruning pellets, a forced draft gasifier with high power primary and secondary air injection (T-LUD, Wood gas) was used. The gasifier fan batteries were precharged. Then, $325 \mathrm{~g}$ of pellets, evenly distributed, with 
a humidity of $7.49 \%( \pm 0.22 \%)$ were placed in the gasifier. Additionally, $75 \mathrm{~g}$ of pellets moistened with 95\% isopropyl alcohol (previously placed in an airtight container to avoid evaporation for $24 \mathrm{~h}$ at room temperature) were also placed inside the gasifier. For the case of traditional technology, a comparison was made to an open fire that uses white oak wood without bark (Quercus bicolor), with a humidity of $12.5 \%( \pm 1.1 \%)$. Moisture on a dry basis was measured with the Protimeter Timbermaster Wood Moisture Meter ${ }^{\circledR}$.

For both devices, the water boil test was used, which is a standardized test for simulating cooking tasks in the residential sector, and for evaluating emissions and energy performance [37] (Figures 1 and 2). The tests were carried out five times for each type of fuel. In the energy part, thermal efficiencies, burning rates and water boiling times were estimated. The determined emissions were: methane $\left(\mathrm{CH}_{4}\right)$, non-methane hydrocarbons $(\mathrm{NMHC})$, carbon dioxide $\left(\mathrm{CO}_{2}\right)$, carbon monoxide $(\mathrm{CO})$, particulate matter 2.5 microns in aerodynamic diameter $\left(\mathrm{PM}_{2.5}\right)$, organic carbon $(\mathrm{OC})$ and elemental carbon (EC). Emission factors were determined using the carbon balance approach, which accounts for the fate of the fuel carbon in the emitted species, and has been used frequently in previous stove emission studies to derive cookstove emission factors [38].

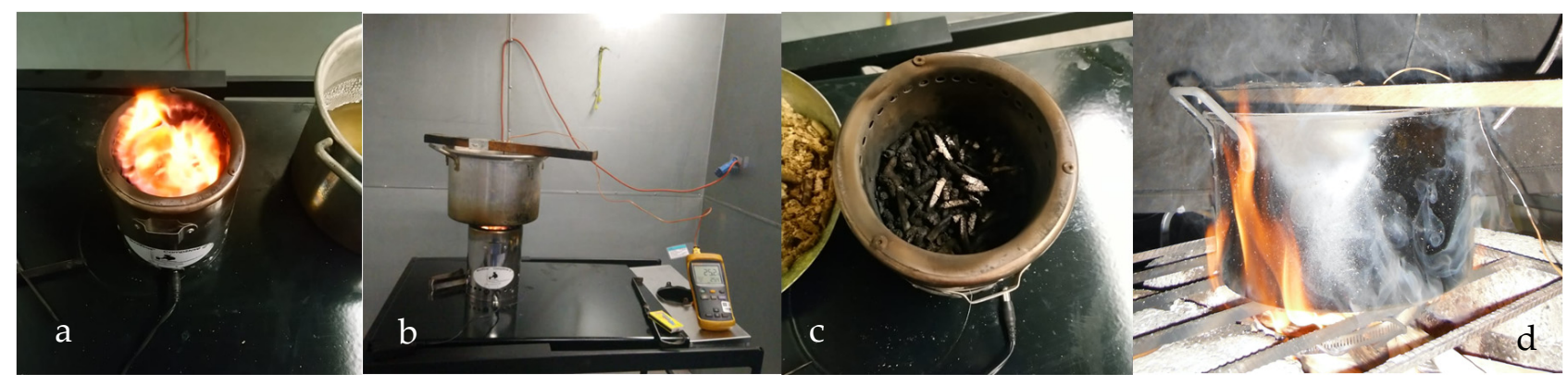

Figure 1. Water boiling test, T-LUD (wood gas) gasifier and three stone open fire. From left to right: (a) start of guava pellet combustion, (b) water boil test with gasifier, (c) residual carbon from pellets guava and (d) open fire with firewood.

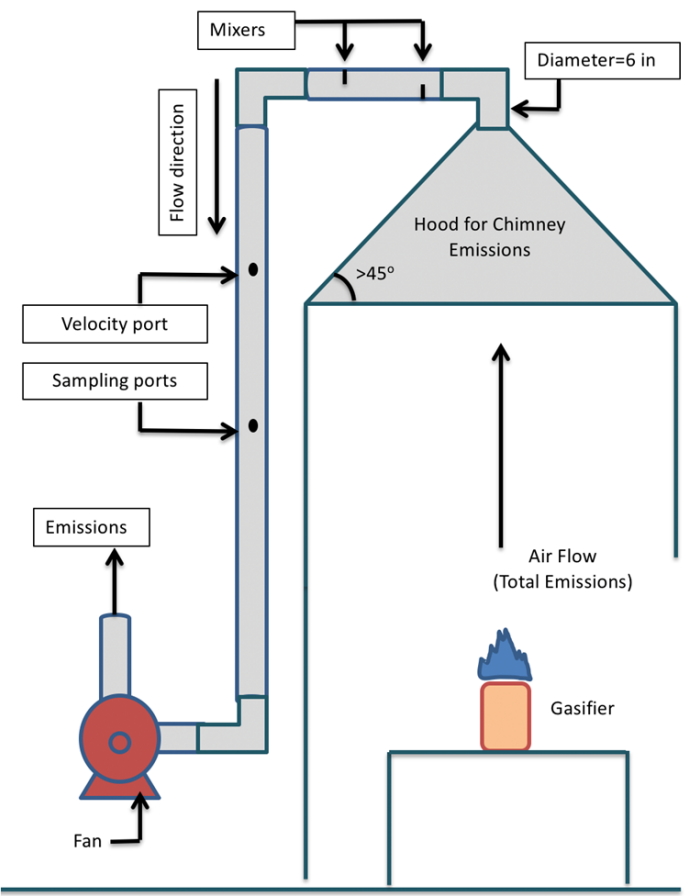

Figure 2. Schematic sampling setup. 


\subsubsection{Particulate Matter}

$\mathrm{PM}_{2.5}$ was measured with the Laboratory Emissions Monitoring System (LEMS) proposed by Aprovecho Research Center (Cottage Grove, OR, USA) and adapted by RuizGarcía et al. [39]. This equipment measures $\mathrm{PM}_{2.5}$ by optical and gravimetric methods. The optical method performs a measurement every $2 \mathrm{~s}$ using a light scattering sensor. On the other hand, the gravimetric method accumulates the mass of $\mathrm{PM}_{2.5}$. For the collection of $\mathrm{PM}_{2.5}$, a laminar flow of $16.7 \mathrm{~L}$ per minute (LPM) was used. $\mathrm{PM}_{2.5}$ was collected on glass fiber filters (4 in) without a hydrophilic binder (FPAE-102), with a cyclone demister (URG, $2.5 \mu \mathrm{m}$ ). The flows to the cyclones were calibrated, before and after each evaluation, using the Defender 510 flow meter. The mass of $\mathrm{PM}_{2.5}$ in the filters was determined with an analytical balance (Microbalance EX225D, OHAUS, Parsippany, NJ, USA) with a maximum capacity of $10 \mathrm{~g}$, a minimum capacity of $10 \mu \mathrm{g}$ and an accuracy of $10 \mu \mathrm{g}$. The balance is located on a concrete bar to eliminate vibrations. Before and after the weighing set, verifications were made with standard masses $(1 \mathrm{mg}, 50 \mathrm{mg}, 200 \mathrm{mg}, 500 \mathrm{mg}, 1000 \mathrm{mg}$ ) and the filters were stabilized for $48 \mathrm{~h}$ at a temperature of $23 \pm 2{ }^{\circ} \mathrm{C}$ and humidity of $35 \pm 5 \%$. A deionizer (Sartorius, Stat-Pen, Göttingen, Germany) was used to remove electrostatic charges on the filters. The deionizer was used on the filters prior to each weighing.

\subsubsection{Organic and Elemental Carbon}

A second gravimetric system was used to measure elemental carbon (EC) and organic carbon (OC). Samples were collected on quartz fiber filters with a sample flow of 3 LPM. The particles collected during the test were analyzed for EC and OC concentration with a thermo-optical carbon analyzer (total inorganic carbon analysis, CM150, UIC Inc., Joliet, IL, USA). The sample was oxidized in an oven (CM5300) at a constant temperature $\left(700{ }^{\circ} \mathrm{C}\right.$ to quantify total carbon and $500{ }^{\circ} \mathrm{C}$ for OC). The $\mathrm{CO}_{2}$ produced in the furnace was brought into a coulometric titration unit (CM5017, UIC Inc., Joliet, IL, USA) to measure the concentration of EC and OC. The sample was oxidized in an oven (CM5300) at a constant temperature ( $1173 \mathrm{~K}$ to quantify total carbon and $773 \mathrm{~K}$ for $\mathrm{OC}$ ). The $\mathrm{CO}_{2}$ produced in the furnace was brought into a coulometric titration unit (CM5017, UIC Inc., Joliet, IL, USA) to measure the concentration of $\mathrm{CO}_{2}$ and estimate the concentration of EC and OC.

\subsubsection{Carbon Monoxide and Dioxide}

LEMS equipment was utilized; the sensor box uses an electrochemical cell to estimate the $\mathrm{CO}$ concentration, and a nondispersive infrared (NDIR) sensor to determine the $\mathrm{CO}_{2}$ concentration. Samples were collected with a sample flow of $4.2 \mathrm{LPM}$. The flows to the sensors were calibrated before and after each test set, using the Defender 510 flow meter. On the other hand, the $\mathrm{CO}$ and $\mathrm{CO}_{2}$ sensors were calibrated using a mixture of $5000 \mathrm{ppm}$ of $\mathrm{CO}_{2}$ and $500 \mathrm{ppm}$ of $\mathrm{CO}$ and nitrogen $\left(\mathrm{N}_{2}\right)$ as adjustment gas, as reported by Ruiz-García et al. [39]. This equipment allows to determine the gas flow temperature with a " $K$ " type thermocouple and the speed was calculated by means of the pressure difference $(\Delta \mathrm{P})$.

\subsubsection{Methane and Short Chain Hydrocarbons}

A Young Lin gas chromatograph (GC Model 6500, Anyangcheondong-ro, Dongan-gu, Korea) was used. This equipment is an analytical system for the quantification of $\mathrm{CH}_{4}$ and NMHC (C1-C5). The gaseous samples are taken continuously (by means of a jacketed probe that has an electrical resistance to avoid a decrease in gas temperature). An injection valve was used to inject $2 \mathrm{~mL}$, using a 1:20 ratio with helium as stripping gas within the column. For the separation of $\mathrm{CH}_{4}$ and $\mathrm{NMHC}$, the exhaust gas sample passes through a capillary column. The gas chromatograph has a high resolution GC column of $60 \mathrm{~m}$ length and $0.320 \mathrm{~mm}$ in diameter, and temperature limits from $-80^{\circ} \mathrm{C}$ to $260{ }^{\circ} \mathrm{C}$ (GS Gaspro, Agilent Technologies, Folsom, CA, USA). A flame ionization detector (FID from YL6500 chromatograph, Anyangcheondongro, Bushan, Korea) was used. Methane and HCNM standard gases were used to construct the calibration curves: 15,100 and $200 \mathrm{ppm}$. 


\section{Results and Discussion}

\subsection{Applied Survey}

The responses to the survey applied in relation to the use of pruning residues in the guava trees orchards in the study area are the following: the material is left in the orchards $(67 \%)$, it is used as firewood (24\%), and it is used as fence posts (9\%). Leaving this material in the orchards causes its decomposition and incorporation into the soil, but while this process is taking place, there could be a risk of proliferation of pests and diseases in the orchards. Therefore, it is considered necessary to reduce the negative impact by seeking a comprehensive management of this biodegradable solid waste [40].

\subsection{Characterization of Selected Biomass Samples}

\subsubsection{Moisture Content}

The initial moisture content in the material obtained by pruning the guava trees was $84 \%( \pm 1.34)$, a relatively high value compared to the $68 \%$ found in pruning material in the same tree species [21]. On the other hand, it is known that the initial moisture in freshly cut lignocellulosic material can be 63\% [41], but ultimately, the result depends on the time of year when the pruning works are carried out [42]. Additionally, the moisture content of the ground biomass dried in the open air was $7.36 \%( \pm 0.06 \%)$, but at the time of pelleting, the moisture of the material had adjusted to approximately $14 \%$.

\subsubsection{Chemical Analysis}

The results obtained from the chemical analysis were the following: $19.85 \%$ of lignin, $48.97 \%$ of cellulose, $13.45 \%$ of hemicellulose, and $16.06 \%$ of other components (extractives). The lignin value is close to the maximum value of the range reported for guava tree branches of $17.9 \%$ to $19.5 \%$ [21]. The percentage of cellulose obtained is higher than the values found in the literature (from $32.7 \%$ to $35.4 \%$ ), while the value of hemicelluloses is lower compared to the reported data of $27.2 \%$ to $34.1 \%$, in branches of different guava trees [21]. Regarding the percentage of extractives, the result obtained here falls within the reported range (from $15.2 \%$ to $21.8 \%$ ) for branches of guava trees [21].

\subsubsection{Proximate Analysis}

The ash content of the pruning biomass was $1.67 \%( \pm 0.07 \%)$, which is a lower value than the results reported for guava trees collected at different altitudes and in different orchards in Mexico (1.9\% to $4.9 \%$ ) [21], and the reported value of $3.7 \%$ for pruning material from orchards in Ecuador [27]. It is known that factors such as age, origin, and species, among others, affect the content of this material [43]. Due to the content of inorganic material, the pellets made with this biomass could reach Class B, for which the requirement is an ash content not higher than 3\% [44]. The amount of volatile matter in the biomass from the pruning of guava trees was $85.25 \%( \pm 1.93 \%)$, which is a value greater than the $77.4 \%$ reported in biomass collected from trees of this same species from Ecuador [27], but in general it is in the range reported for biomass ( $47.8 \%$ to $86.3 \%)$ [41]. The fixed carbon calculated in the biomass sample was $13.05 \%( \pm 1.00 \%)$ and is within the range reported for biomass ( $0.5 \%$ to $37.9 \%)$ [41]. This obtained value is comparable with data reported for sawdust from Swartzia cubensis (13.1\%), Pinus spp. (13.1\%) and slightly less than the $12.1 \%$, found in Persian lime branches [45].

\subsubsection{Ultimate Analysis}

The result of the elemental analysis was as follows: carbon $46.83 \%( \pm 0.03), 5.76 \%$ $( \pm 0.20)$ hydrogen, $46.82 \%( \pm 0.17)$ oxygen, $0.59 \%( \pm 0.00)$ nitrogen, and $0.01 \%( \pm 0.00)$ sulfur. The carbon content is lower than the value found $(49.65 \%)$ in the pruning of guava trees [27], and lower than the range reported for Pinus spp. (49.5\% to 50.8\%), for oak woods (50.0\% to $50.6 \%$ ) and for tropical woods ( $49.1 \%$ to $49.9 \%$ ) [45]. On the other hand, the obtained hydrogen content is close to that reported for the pruning biomass of guava trees (5.99\%) [27] and slightly lower than the range found for Pinus spp. (6.2\% to $6.6 \%)$, for 
oak woods (5.9\% to $6.0 \%)$ and for tropical woods $(6.0 \%$ to $6.2 \%)$ [45]. Furthermore, the nitrogen concentration is close to $0.68 \%$, which was found in the pruning biomass of guava trees [27] and is within the range found for Pinus spp. (0.1\% to 0.74\%) [45]. On the other hand, the amount of sulfur is low compared to the value of $0.068 \%$, found in the biomass from pruning guava trees [27] and is considerably low compared to the range reported for charcoal $(0.2 \%$ to $9.8 \%)$ [46,47]. Finally, the results of the elemental analysis of the biomass derived from the pruning of guava trees generally coincide with data reported for various types of biomass [41].

\subsubsection{Ash Microanalysis}

With the methodology used, the presence of 29 chemical elements in the ash samples was searched. The obtained results indicate the presence of the following 17 chemical elements: aluminum (191.30 ppm), boron (188.23 ppm), barium (412.30 ppm), calcium (4610.61 ppm), copper (113.70 ppm), iron (174.40 ppm), potassium (13373.68 ppm), lithium (124.98 ppm), magnesium (1391.37 ppm), manganese (339.37 ppm), sodium (1897.53 ppm), nickel (6.89 ppm), phosphorus (15744.31 ppm), silicon (467.15 ppm), tin (1.18 ppm), strontium (353.34 ppm), vanadium (0.53 ppm), and zinc (138.86 ppm). The chemical elements that were not found by the applied method were the following: silver, astate, beryllium, cadmium, cobalt, chromium, molybdenum, lead, antimony, selenium, and thallium; some of them are usually found in timber biomass ash $[43,45]$. The elements with the highest concentration were phosphorus, potassium and calcium, which generally correspond to the chemical composition of ash from wood [43]. Some chemical elements detected here generally coincide with the results reported in ash from guava pruning residues, collected in orchards located at different altitudes [21]. In general, these results coincide with previous reports carried out with different wood species [45,48-52].

On the other hand, the chemical elements of the studied biomass, whose concentration is within the typical variation for pruning residues from hardwood according to the UNEEN 1491-1 [53] standard, were the following: aluminum, calcium, iron, manganese, nickel, and vanadium; while the chemical elements that exceeded the typical variation were: copper (3000 to 5000 ppm), potassium (1000 to $4000 \mathrm{ppm}$ ), magnesium (100 to $400 \mathrm{ppm}$ ), sodium (20 to $200 \mathrm{ppm}$ ), phosphorus (30 to 1000), silicon (75 to $250 \mathrm{ppm}$ ), and zinc (2 to $100 \mathrm{ppm})$.

Several investigations indicate that the problems caused in the combustion process by high concentrations of certain chemical elements in biomass are the following: potassium lowers the ash melting point and forms slag, scale, aerosols and fine particles [54,55], magnesium increases the ash melting point [56], phosphorus can cause problems in the ash melting process [56], sodium reduces the ash melting point [56] and forms deposits [57]. Finally, to evaluate the potential use of these pellets in a larger scale application, it should be necessary to assess the melting point of the ash and the formation of aerosols. Finally, for the energy potential use of these pellets in a larger scale application, it is necessary to assess the melting point of the ash and the formation of aerosols.

\subsection{Thermal Behavior: TGA and DTG Analysis}

Currently, in the study of the behavior and thermal degradation of lignocellulosic biomass composed of cellulose, hemicellulose and lignin, thermogravimetric analysis (TGA) and its derivative, i.e., differential thermogravimetric analysis (DTG), are widely recognized in pyrolysis processes [58]. Figure 3 shows the thermal degradation of biomass. This figure is divided into three totally differentiated zones in both the TGA and DTG graphs. In Zone I, the first dehydration process takes place, where it can be observed that the variation of the mass of the sample with respect to the temperature is very small (about $2-5 \%$ ). A peak is located between 25 and $150{ }^{\circ} \mathrm{C}$ and represents approximately $10 \%$ of the biomass; where mainly surface water and a certain amount of intercellular water has been lost, there is also a loss of some low molecular weight volatiles. In the range of $150-400{ }^{\circ} \mathrm{C}$, a second zone (Zone II) is observed, also known as active pyrolysis, as well as a second peak, 
where pyrolytic cracking takes place, which represents the most important degradation corresponding to cellulose and hemicellulose [59]. Such degradation corresponds to more than $50 \%$ of the biomass. In this zone, lignin degradation has also been reported, but in a very small percentage, in addition to the formation of a significant amount of volatile material [60]. In this stage of the pyrolytic process, the highest mass loss rate $\left(\approx 14 \% /{ }^{\circ} \mathrm{C}\right)$ is observed at a temperature of approximately $350^{\circ} \mathrm{C}$. Finally, in Zone III, also known as the passive zone of the pyrolytic process, it is observed that, starting at $400{ }^{\circ} \mathrm{C}$, there is a slope with less steepness in both the TGA and DTG graphs, which represents the complete degradation of the volatile compounds derived from hemicellulose and cellulose from Zone II. However, this zone is mainly dominated by the degradation of lignin and some inorganic compounds called carbonaceous solids [61]. It is observed that at the end of Zone III, there is practically no more degradation of guava biomass, which means that the pyrolytic process has ended and, therefore, charcoal has been formed.

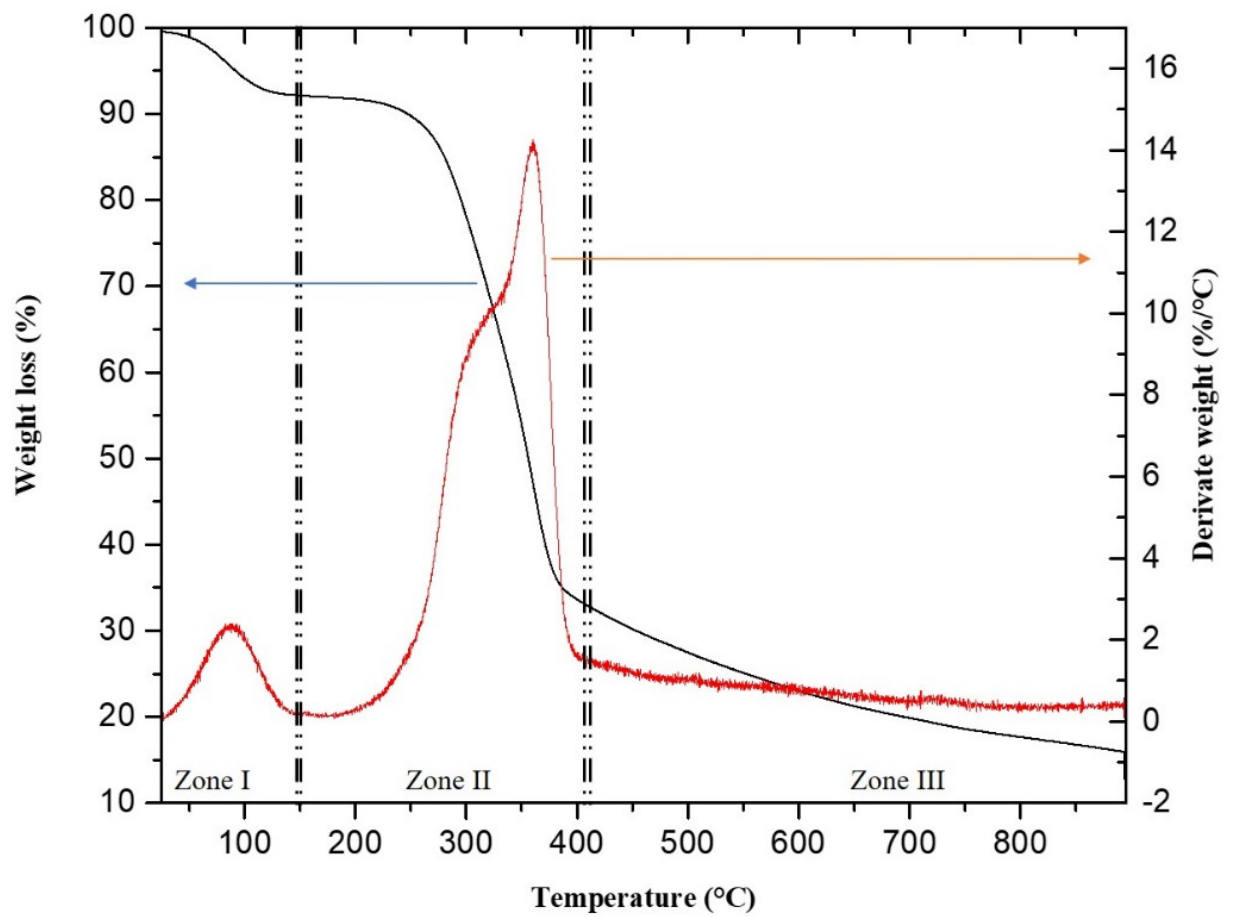

Figure 3. TGA-DTG analysis of guava tree pruning in an inert atmosphere.

\subsection{Characterization of Pellets Samples}

\subsubsection{Moisture Content}

The moisture content of the guava pellets was $7.49 \%( \pm 0.22 \%)$, which satisfies the requirement that the moisture content in the quality of the pellets should be less than $15 \%$ [62], and, with this value, the produced pellets can reach the super premium classification, whose requirement is a moisture of less than or equal to $8 \%$ [63]. In other investigations, different moisture values have been reported, for example, for pellets made with sawdust from tropical common woods, the moisture varied from 4.6 to $6.7 \%$ [64], and in sawdust pellets from Pinus spp., the moisture ranged from 7.0 to $11.0 \%$ [65].

\subsubsection{Particle Density}

The average particle density, known as real density $[10,66]$, was $1.05 \mathrm{~g} / \mathrm{cm}^{3}( \pm 0.11)$ and is practically at the lower limit of the range reported in a manual for pellets (1.12 to $1.30 \mathrm{~g} / \mathrm{cm}^{3}$ ) [56]. No information was available regarding the density of pellets obtained from the pruning of guava tree residues, however, the value obtained here is close to that reported for pellets made with Acacia wrightii wood $\left(1.18 \mathrm{~g} / \mathrm{cm}^{3}\right.$, at $6.74 \%$ moisture), from Ebenopsis ebano $\left(1.10 \mathrm{~g} / \mathrm{cm}^{3}\right.$, at $4.62 \%$ moisture), Havardia pallens $\left(1.12 \mathrm{~g} / \mathrm{cm}^{3}\right.$, at $6.18 \%$ 
mositure) [64], and slightly lower than the value reported for pellets made with sawdust from Pinus spp. (1.23 g/ $\mathrm{cm}^{3}$, at $7.0 \%$ moisture) [64]. It is known that the final density of densified materials is influenced by the same density of the material used and by the pressure exerted by the press when compacting the biomass [66].

\subsubsection{Bulk Density}

The bulk density of the guava pellets was $607.3 \mathrm{~kg} / \mathrm{m}^{3}( \pm 6.02)$. This value is close to the minimum value $\left(600 \mathrm{~kg} / \mathrm{m}^{3}\right)$ for the bulk density of pellets [67]. No information was available regarding the bulk density of pellets made from guava tree pruning residues. In a similar pelletizing process, using sawdust from Pinus spp., a bulk density of 606 to $646 \mathrm{~kg} / \mathrm{m}^{3}$ was obtained [65]. When using oak wood sawdust, bulk densities of $222 \mathrm{~kg} / \mathrm{m}^{3}$ (Quercus rugosa) and $246 \mathrm{~kg} / \mathrm{m}^{3}$ (Quercus laeta), were reported [68]. On the other hand, an investigation revealed a density of $590 \mathrm{~kg} / \mathrm{m}^{3}$ for pine and fir wood pellets [69]. This density is of utmost importance for the transportation, handling and storage of densified biofuels [66].

\subsubsection{Impact Resistance}

The impact resistance of the guava pellets was $90.33 \%$, which is lower compared to pellets obtained from wood of common tropical species (Acacia wrightii, Ebenopsis ebano, Havardia pallens), ranging from 117 to 160 [64]. In this research, in particular, the authors also used a particle size smaller than $4 \mathrm{~mm}$, so this difference in impact resistance could be due to the density of the woods [66].

\subsubsection{Heating Value}

The higher heating value (HHV) for the ground biomass was $19.37 \mathrm{MJ} / \mathrm{kg}( \pm 0.22 \mathrm{MJ} / \mathrm{kg})$ and for guava pellets, it was $19.52 \mathrm{MJ} / \mathrm{kg}( \pm 0.38 \mathrm{MJ} / \mathrm{kg})$. These values are slightly higher than the value found of $18.42 \mathrm{MJ} / \mathrm{kg}$, also for the pruning biomass of guava trees grown in Ecuador [27]. These results are comparable with data reported for pine sawdust (19.7 MJ $/ \mathrm{kg}$ to $19.9 \mathrm{MJ} / \mathrm{kg})$, for Persian lime branches $(19.80 \mathrm{MJ} / \mathrm{kg}$ ) and for orange branches (19.83 MJ $/ \mathrm{kg})$, calculated based on their ash content [45]. Finally, the obtained results are practically located in the range of $19.5 \mathrm{MJ} / \mathrm{kg}$ to $20.0 \mathrm{MJ} / \mathrm{kg}$ reported for hardwood felling residues [53], and, according to the range considered (18 to $20 \mathrm{MJ} / \mathrm{kg}$ ) [70], our pellets could be suitable for heating applications in the commercial or industrial sector (see Table 1).

Table 1. Higher heating values of different types of biomass.

\begin{tabular}{|c|c|c|c|}
\hline Biomass Type & HHV (MJ/kg) & Carbon Content (\%) & Reference \\
\hline Pruning biomass of guava trees & $19.37 \pm 0.22$ & \multirow{2}{*}{$46.83 \%$} & (this study) \\
\hline Guava pellets & $19.52 \pm 0.38$ & & (this study) \\
\hline Pruning biomass of guava trees & 18.42 & 49.65 & [25] \\
\hline Pine sawdust & 19.7 to 19.9 & 49.5 to 50.8 & [45] \\
\hline Persian lime branches & 19.80 & \multirow{2}{*}{49.1 to 49.9} & {$[45]$} \\
\hline Orange branches & 19.83 & & [45] \\
\hline Hardwood felling residues & 19.5 to 20.0 & 50.0 to 50.6 & {$[70]$} \\
\hline $\begin{array}{l}\text { Pellets for heating applications in } \\
\text { the commercial or industrial sector }\end{array}$ & 18.0 to 20.0 & - & [70] \\
\hline
\end{tabular}

The energy density of guava pellets was $13.4 \mathrm{GJ} / \mathrm{m}^{3}$, which is a value close to reported data of $12.0 \mathrm{GJ} / \mathrm{m}^{3}$ for white commercial wood pellets, $12.9 \mathrm{GJ} / \mathrm{m}^{3}$ for brown commercial wood pellets, $11.8 \mathrm{GJ} / \mathrm{m}^{3}$ for pine woodchips [71] and $14.15 \mathrm{GJ} / \mathrm{m}^{3}$ for pine pellets [72]. Factors such as the quality of the original biomass and the applied densification process, strongly reflect the energy density obtained [73]. Additionally, it is known that the energy 
density of biofuel is affected by the bulk density, and, therefore, has an impact on the logistics costs of biofuel management [74,75].

\subsection{Energy Performance and Greenhouse Gases Produced by the Combustion of Pellets}

Table 2 shows the emission factors for each type of analyzed fuel. In the task of heating water, there is a reduction in emissions from the combustion of guava pellets in a gasifier compared to the use of an open fire that uses wood. The contribution of methane from the use of guava pellets is half compared to the combustion of firewood over an open fire. Regarding the HCNM, there is a reduction by three times in relation to firewood, and, finally, for $\mathrm{PM}_{2.5}$ there is a reduction by five times due to the use of pellets with respect to firewood to perform the same task.

The emission rates for all the evaluated pollutants are lower in guava pellets than in firewood due to the lower fuel consumption in the gasifier. In addition, the injection of secondary air in the gasifier reduces the secondary products of combustion, which produces better oxygen flows that do not cool the combustion chamber, as described by Ruíz-García et al. [39]. It is important to note that the gasifier reduces the emission rates of short chain hydrocarbons ( $\mathrm{C} 1-\mathrm{C} 5)$ with respect to an open fire by almost ten times, and the emission rates of $\mathrm{CH}_{4}$ by $20 \%$.

Regarding the emissions per MJ consumed, the gasifier with guava pellets presents lower emissions in all the evaluated pollutants. In the case of the $\mathrm{PM}_{2.5}$ emissions, they have an order of magnitude 8 times less than firewood, almost 5 times in the HCNM, 3 times for $\mathrm{CH}_{4}, 7$ times for $\mathrm{CO}, 6$ times with respect to the $\mathrm{EC}$ and almost 30 times for the OC.

In the emissions of firewood from the stove, $\mathrm{CO}_{2}$ represents $96 \%$ of the total measured emissions, while for the gasification of guava pellets it represents $98 \%$. This slight variation $(2 \%)$ in the pellets represents an important contribution to the reduction of secondary combustion products, such as methane and elemental carbon, that contribute to climate change and there are currently national and global efforts to mitigate them. In the case of particulate matter, the decrease in the emissions of this pollutant will help to improve the quality of the air both inside and outside the walls. These reductions contribute to improvements in the health of users.

The WHO [76] recommends emission rates lower than $7.15 \mathrm{mg} / \mathrm{min}$ of $\mathrm{PM}_{2.5}$ in ventilated spaces to comply with the Air Quality Guidelines (AQGs) (intermediate emission rate targets), which indicates that emission rates should be lower than those reported in this study by the gasification of guava pellets. On the other hand, there are other international indicators to evaluate this type of emissions. For the case of the guidelines (default emission rates), suggested in the ISO/TR 19867-3 [37] protocol for cooking devices, the emission rate of the evaluated pellets $(9 \mathrm{mg} / \mathrm{min}$ ) represents a level 3 indicator (the scale being from zero to five, where zero is the lowest and most polluting, and five is the highest and cleanest). In the case of the open fire, the emission rates are very high $(128 \mathrm{mg} / \mathrm{min})$, according to the WHO AQGs $\left(7.15 \mathrm{mg} / \mathrm{min}\right.$ ) for $\mathrm{PM}_{2.5}$. On the other hand, regarding $\mathrm{CO}$, the WHO recommends emission rates of $1450 \mathrm{mg} / \mathrm{min}$ to comply with the 24-h AQGs [76]. Therefore, the gasifier emission rates comply with the 24-h guidelines since they have a value of $557 \pm 24 \mathrm{mg} / \mathrm{min}$ of $\mathrm{CO}$, but the same cannot be said for the stove, which has a value of $1491 \pm 178 \mathrm{mg} / \mathrm{min}$. In the case of the indicators proposed by the ISO/TR [37], the $\mathrm{CO}$ emission rates in the gasifier have a level 1 , while the open fire has a level 0 . This means that there are still opportunities to improve the performance and emissions in gasifiers that use guava pellets. In the case of $\mathrm{CH}_{4}$ and $\mathrm{HCNM}$ emissions, there are no standards in the regulations. However, there are evaluations in field water boil tests for improved stoves and open fires that use wood. Johnson et al. [38] report emission factors in field water boiling tests of $2800 \pm 2667 \mathrm{mgCH}_{4} / \mathrm{kg}$ of oak firewood for an open fire and $933 \pm 933 \mathrm{mgCH}_{4} / \mathrm{kg}$ of oak firewood for an improved stove (Patsari), while in our study there are emission factors of $426 \pm 211 \mathrm{mgCH}_{4} / \mathrm{kg}$ for guava pellets and $857 \pm 324 \mathrm{mgCH}_{4} / \mathrm{kg}$ of firewood for the open fire evaluated in the laboratory. Quiñones- 
Reveles et al. [77], in evaluations of forest residue pellets, reported $114 \pm 10 \mathrm{mgCH}_{4} / \mathrm{kg}$ of Quercus Sideroxyla pellets with bark and $91 \pm 10 \mathrm{mgCH}_{4} / \mathrm{kg}$ of Juniperus deppeana pellets without bark. These values represent the range of 13 evaluated samples. Emission factors for all the pollutants measured for Guava pellets are higher than pellets from forest species (except for EC and OC emissions). The foregoing shows that the use of pellets through gasification processes is an option to satisfy heating needs in the residential sector, at the same time it mitigates half of the methane emissions compared to an improved stove that uses firewood. In the case of the EC and OC emissions, an open fire with oak wood emits $1001 \pm 91 \mathrm{mgEC} / \mathrm{kg}$ and $1638 \pm 1001 \mathrm{mgOC} / \mathrm{kg}$, while an efficient stove emits $728 \pm 1001 \mathrm{mgEC} / \mathrm{kg}$ and $1001 \pm 1183 \mathrm{mgOC} / \mathrm{kg}$ of dry firewood. In the case of guava pellets, the emissions were $124 \pm 132 \mathrm{mgEC} / \mathrm{kg}$ and $65 \pm 51 \mathrm{mgOC} / \mathrm{kg}$ of dry pellets consumed.

Table 2. Results of the evaluation of greenhouse gases and energy performances in a water boiling test.

\begin{tabular}{|c|c|c|c|c|}
\hline Device & \multicolumn{3}{|c|}{ T-LUD (Wood Gas) } & \multirow{2}{*}{$\begin{array}{c}\text { Three Stone } \\
\text { Stove }\end{array}$} \\
\hline Fuel Type & $\begin{array}{l}\text { Guava } \\
\text { Pellets }\end{array}$ & $\begin{array}{c}\text { Arbutus } \\
\text { xalapensis } \\
\text { (with Bark) * }\end{array}$ & $\begin{array}{c}\text { Juniperus } \\
\text { deppeana Pellets } \\
\text { (without Bark)* }\end{array}$ & \\
\hline \multicolumn{5}{|c|}{ Energy performance } \\
\hline Dry fuel & $328 \pm 20$ & $360 \pm 1$ & $366 \pm 10$ & $629 \pm 45$ \\
\hline Burn rate $(\mathrm{g} / \mathrm{min})$ & $13 \pm 2$ & $11 \pm 1$ & $9 \pm 2$ & $27 \pm 7$ \\
\hline Thermal efficiency (\%) & $20 \pm 1$ & $31 \pm 3$ & $30 \pm 2$ & $17 \pm 1$ \\
\hline Available power (Kw) & $4 \pm 1$ & $3 \pm 1$ & $3 \pm 1$ & $8 \pm 2$ \\
\hline Time $(\mathrm{min})$ & $26 \pm 2$ & $34 \pm 2$ & $39 \pm 6$ & $24 \pm 5$ \\
\hline \multicolumn{5}{|c|}{ Emission factors per kg of dry fuel consumed } \\
\hline $\mathrm{gCO}_{2}$ & $859 \pm 97$ & $1247 \pm 15$ & $1140 \pm 74$ & $1127 \pm 118$ \\
\hline $\mathrm{gCO}$ & $9 \pm 2$ & $9 \pm 1$ & $4 \pm 1$ & $39 \pm 12$ \\
\hline $\mathrm{mgCH}_{4}$ & $426 \pm 211$ & $105 \pm 11$ & $105 \pm 13$ & $857 \pm 324$ \\
\hline mgNMHC & $583 \pm 66$ & $263 \pm 76$ & $110 \pm 57$ & $1607 \pm 794$ \\
\hline $\mathrm{mgPM}_{2.5}$ & $668 \pm 181$ & $315 \pm 125$ & $91 \pm 22$ & $3370 \pm 1292$ \\
\hline mgEC & $124 \pm 132$ & $133 \pm 97$ & $73 \pm 17$ & $482 \pm 168$ \\
\hline mgOC & $65 \pm 51$ & $101 \pm 18$ & $15 \pm 3$ & $1219 \pm 426$ \\
\hline \multicolumn{5}{|c|}{ Emission rate per minute } \\
\hline $\mathrm{gCO}_{2}$ & $11 \pm 1$ & $13 \pm 1$ & $11 \pm 1$ & $46 \pm 12$ \\
\hline $\mathrm{mgCO}$ & $557 \pm 24$ & $95 \pm 8$ & $39 \pm 5$ & $1491 \pm 178$ \\
\hline $\mathrm{mgCH}_{4}$ & $27 \pm 2$ & $1 \pm 1$ & $1 \pm 1$ & $34 \pm 15$ \\
\hline mgNMHC & $7 \pm 1$ & $3 \pm 1$ & $1 \pm 1$ & $66 \pm 40$ \\
\hline $\mathrm{mgPM}_{2.5}$ & $9 \pm 3$ & $3 \pm 1$ & $1 \pm 1$ & $128 \pm 21$ \\
\hline mgEC & $2 \pm 2$ & $1 \pm 1$ & $1 \pm 0$ & $18 \pm 3$ \\
\hline mgOC & $1 \pm 1$ & $1 \pm 1$ & $<1 \pm 0$ & $47 \pm 7$ \\
\hline \multicolumn{5}{|c|}{ Emission factors per MJ consumed } \\
\hline $\mathrm{gCO}_{2}$ & $49 \pm 6$ & $73 \pm 1$ & $63 \pm 4$ & $107 \pm 1$ \\
\hline $\mathrm{mgCO}$ & $507 \pm 133$ & $514 \pm 24$ & $230 \pm 53$ & $3623 \pm 834$ \\
\hline $\mathrm{mgCH}_{4}$ & $24 \pm 12$ & $6 \pm 1$ & $6 \pm 1$ & $82 \pm 30$ \\
\hline mgNMHC & $33 \pm 4$ & $15 \pm 4$ & $6 \pm 3$ & $152 \pm 72$ \\
\hline $\mathrm{mgPM}_{2.5}$ & $38 \pm 10$ & $18 \pm 7$ & $5 \pm 1$ & $315 \pm 95$ \\
\hline mgEC & $7 \pm 8$ & $8 \pm 6$ & $4 \pm 1$ & $45 \pm 12$ \\
\hline $\mathrm{mgOC}$ & $4 \pm 3$ & $6 \pm 1$ & $1 \pm 0$ & $114 \pm 31$ \\
\hline
\end{tabular}

Note: * Data from Quiñones-Reveles et al. [77].

Figure 4 shows a correlation between $\mathrm{PM}_{2.5}$ and $\mathrm{OC}$ in different types of biomass. With the results of this study and the literature, the correlation includes 14 species of pellets with bark and without bark combusted in a gasifier [77] and two types of firewood in improved stoves and open fires [38]. There is a correlation of $\mathbf{R}^{2}=0.97(p<0.05)$ for the 
15 analyzed biomass species and a correlation of $R^{2}=0.95(p<0.05)$ considering only the types of biomass evaluated in this study. Thompson et al. [78] analyzed cooking devices that use mixtures of charcoal, woody biomass and agricultural residual, and they obtained a significant correlation between $\mathrm{PM}_{2.5}$ and organic matter $(\mathrm{OM})$ of $\mathrm{R}^{2}=0.94(p<0.05)$. $\mathrm{OM}=1.9^{*} \mathrm{OC}$.

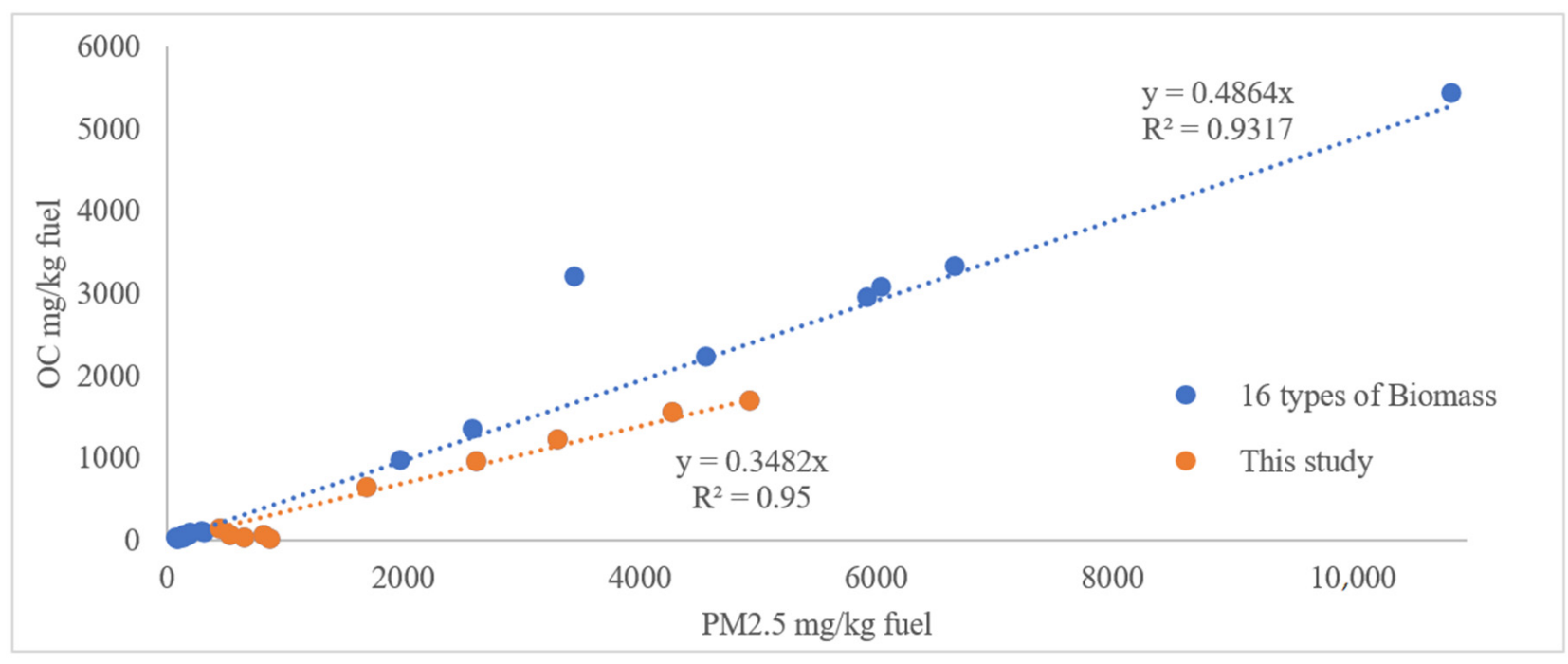

Figure 4. Correlation between 2.5 microns particulate matter $\left(\mathrm{PM}_{2.5}\right)$ and organic carbon $(\mathrm{OC})$ in different types of biomass. Note: The 15 types of biomass are detailed in the studies by Johnson et al. [38], Quiñones-Reveles et al. [77] and in this study. They include 14 species of pellets (with and without bark) and 2 types of firewood (pine and oak with and without bark).

\section{Conclusions}

Due to the content of inorganic substances (mainly ash), this biomass can be used to make class $\mathrm{B}$ pellets. Guava pellets evaluated with respect to open fires mitigate $\mathrm{CO}_{2}, \mathrm{CO}$, $\mathrm{CH}_{4}, \mathrm{HCNM}, \mathrm{EC}, \mathrm{OC}$, and $\mathrm{PM}_{2.5}$ emissions. Emissions per unit of energy consumed were reduced by 8 times for $\mathrm{PM}_{2.5}$, almost 5 times for $\mathrm{HCNM}, 3$ times for $\mathrm{CH}_{4}, 7$ times for $\mathrm{CO}$, 2 times for $\mathrm{CO}_{2}, 6$ times with respect to the $\mathrm{EC}$ and almost 30 times for the OC. Finally, the results of the physical and energetic characterization of the pellets indicate, in general, a good potential for their use as solid densified biofuels.

Author Contributions: Conceptualization, V.M.R.-G. and J.G.R.-Q.; formal analysis, M.Y.H.-M. and J.C.V.-T.; funding acquisition, V.M.R.-G. and J.G.R.-Q.; methodology, V.M.R.-G., J.J.A.-F., V.M.B.-S. and J.G.R.-Q.; writing—original draft, V.M.R.-G., J.J.A.-F., P.L.-A., O.M. and J.G.R.-Q.; writing-review and editing, V.M.R.-G. and J.G.R.-Q. All authors have read and agreed to the published version of the manuscript.

Funding: This research was supported by UMSNH (Grant number CIC-21.3-JGRQ), PAPIIT (Grant number IA105820), PAPIIT (Grant number IG101121), and SENER-CONACYT (CEMIE-Bio) grant number 246911 "Clúster de biocombustibles sólidos para generación térmica y eléctrica".

Institutional Review Board Statement: Not applicable.

Informed Consent Statement: Not applicable.

Data Availability Statement: Not applicable.

Acknowledgments: Authors thank the support of UMSNH, UNAM, SENER-CONACYT and ISN.

Conflicts of Interest: The authors declare no conflict of interest. 


\section{References}

1. García, C.A.; Riegelhaupt, E.; Masera, O. Introducción. In Estado del Arte de la Bioenergía en México, Red Temática de Bioenergía (RTB) del CONACYT; García-Bustamante, C.A., Masera, O., Eds.; Imagia Comunicación: Guadalajara, Mexico, 2016; pp. 9-14.

2. Sovacool, B.K. How long will it take? Conceptualizing the temporal dynamics of energy transitions. Energy Res. Soc. Sci. 2016, 13, 202-215. [CrossRef]

3. Burke, M.J.; Stephens, J. Energy democracy: Goals and policy instruments for sociotechnical transitions. Energy Res. Soc. Sci. 2017, 33, 35-48. [CrossRef]

4. Hernández, J.C.A. Ley de Transición Energética, México. 2015. Available online: http://bibliodigitalibd.senado.gob.mx/handle/ $123456789 / 2315$ (accessed on 26 January 2021).

5. Rennkamp, B.; Haunss, S.; Wongsa, K.; Ortega, A.; Casamadrid, E. Competing coalitions: The politics of renewable energy and fossil fuels in Mexico, South Africa and Thailand. Energy Res. Soc. Sci. 2017, 34, 214-223. [CrossRef]

6. Moran, P.; Goggins, J.; Hajdukiewicz, M. Super-insulate or use renewable technology? Life cycle cost, energy and global warming potential analysis of nearly zero energy buildings (NZEB) in a temperate oceanic climate. Energy Build. 2017, 139, 590-607. [CrossRef]

7. Wang, C.; Chang, Y.; Zhang, L.; Pang, M.; Hao, Y. A life-cycle comparison of the energy, environmental and economic impacts of coal versus wood pellets for generating heat in China. Energy 2017, 120, 374-384. [CrossRef]

8. Van Dael, M.; Lizin, S.; Swinnen, G.; Van Passel, S. Young people's acceptance of bioenergy and the influence of attitude strength on information provision. Renew. Energy 2017, 107, 417-430. [CrossRef]

9. González-Velasco, J. Energías Renovables; Editorial Reverté: Barcelona, Spain, 2009.

10. Velázquez-Martí, B. Aprovechamiento de la Biomasa para uso Energético, 2nd ed.; Editorial Reverté: Barcelona, Spain, 2018.

11. Sovacool, B.K.; Bergman, N.; Hopkins, D.; Jenkins, K.E.; Hielscher, S.; Goldthau, A.; Brossmann, B. Imagining sustainable energy and mobility transitions: Valence, temporality, and radicalism in 38 visions of a low-carbon future. Soc. Stud. Sci. 2020, 50, 642-679. [CrossRef]

12. SENER. Balance Nacional de Energía 2018. 2019. Available online: https://www.gob.mx/cms/uploads/attachment/file/528054 /Balance_Nacional_de_Energ_a_2018.pdf) (accessed on 28 May 2020).

13. Riegelhaupt, E. Biocombustibles sólidos. In Estado del Arte de la Bioenergía en México, Red Temática de Bioenergía (RTB) del CONACYT; García-Bustamante, C.A., Masera, O., Eds.; Imagia Comunicación: Guadalajara, Mexico, 2016; pp. $23-33$.

14. SIAP. El Poder de la Guayaba. 2019. Available online: http:/ / www.gob.mx/siap/articulos/el-poder-de-la-guayaba (accessed on 11 May 2021).

15. PFC. Guayaba. Rica en Sabor y Propiedades. 2020. Available online: http://www.gob.mx/profeco/articulos/guayaba-rica-ensabor-y-propiedades?idiom=es (accessed on 11 May 2021).

16. Damián-Nava, A.; González-Hernández, V.A.; Sánchez-García, P.; Peña-Valdivia, C.B.; Livera-Muñoz, M.; Brito-Guadarrama, T. Crecimiento y fenología del Guayabo (Psidium guajava L.) cv. "Media-china" en Iguala, Guerrero. Rev. Fitotecn. Mex. 2004, 4, 349-358.

17. González-Gaona, E.; Padilla-Ramírez, J.S.; Reyes-Muro, L.; Perales-de la Cruz, M.A.; Esquivel-Villagrana, F. Guayaba su Cultivo en México. Libro Técnico No 1; Instituto Nacional de Investigaciones Forestales, Agrícolas y Pecuarias, Centro de Investigación Regional Norte Centro, Campo Experimental Pabellón: México, Mexico, 2002.

18. Rahim, N.; Gomes, D.J.; Watanabe, H.; Rahman, S.R.; Chomvarin, C.; Endtz, H.P.; Alam, M. Antibacterial activity of Psidium guajava leaf and bark against multidrug-resistant Vibrio cholerae: Implication for cholera control. Jpn. J. Infect. Dis. 2010, 63, 271-274.

19. Dakappa, S.S.; Adhikari, R.; Timilsina, S.S.; Sajjekhan, S. A review on the medicinal plant Psidium guajava Linn. (myrtaceae). J. Drug Deliv. Ther. 2013, 3, 162-168. [CrossRef]

20. Braga, T.V.; das Dores, R.G.R.; Ramos, C.S.; Evangelista, F.C.G.; Tinoco, L.M.D.S.; Varotti, F.D.P.; Carvalho, M.D.G.; Sabino, A.D.P. Antioxidant, Antibacterial and Antitumor Activity of Ethanolic Extract of the Psidium guajava Leaves. Am. J. Plant Sci. 2014, 5, 3492-3500. [CrossRef]

21. Camarena-Tello, J.C.; Rocha-Guzmán, N.E.; Gallegos-Infante, J.A.; González-Laredo, R.F.; Pedraza-Bucio, F.E.; López-Albarrán, P.; Herrera-Bucio, R.; Rutiaga-Quiñones, J.G. Chemical composition of biomass generated in the guava tree pruning. EXCLI J. 2015, 14, 204-212. [CrossRef] [PubMed]

22. Moreno-Jiménez, M.R.; Rocha-Guzmán, N.E.; Rutiaga-Quiñones, J.G.; Medrano-Núñez, D.; Rojas-Contreras, J.A.; GonzálezLaredo, R.F.; Gallegos-Infante, J.A. Polyphenolic Profile, Sugar Consumption and Organic Acids Generation along Fermentation of Infusions from Guava (Pisidium guajava) by the Kombucha Consortium. Recent Res. Sci. Technol. 2018, 10, 16-22. [CrossRef]

23. You, D.-H.; Park, J.-W.; Yuk, H.-G.; Lee, S.-C. Antioxidant and tyrosinase inhibitory activities of different parts of guava (Psidium guajava L.). Food Sci. Biotechnol. 2011, 20, 1095-1100. [CrossRef]

24. Hindi, S.S.Z. Contribution of Parent Wood to the Final Properties of the Carbonaceous Skeleton via Pyrolysis. Int. J. Sci. Eng. Investig. 2012, 1, 9-12.

25. Ibe, C.; Jacobs, C.C.; Imo, C.; Osuocha, K.U.; Okoronkwo, M.U. Evaluation of the Antioxidant Activities of Psidium guajava and Aloe vera. Br. J. Pharm. Res. 2014, 4, 397-406. [CrossRef]

26. Lucas, E.; Olorunnisola, A.; Adewole, N. Preliminary Evaluation of Guava (Psidium guajava L.) Tree Branches for Truss Fabrication in Nigeria. Agr. Eng. Int. CIGR J. 2006, 8, 1-10. 
27. Ivanova, T.; Mendoza Hernández, A.H.; Bradna, J.; Fernández Cusimamani, E.; García Montoya, J.C.; Armas Espinel, D.A. Assesment of guava (Psidium guajava L.) wood biomass for briquettes' Production. Forests 2018, 9, 613. [CrossRef]

28. EN ISO 18134-3 (2016); Solid Biofuels. Determination of Moisture Content. Oven Dry Method. Part 3: Moisture in General Analysis Sample. European Standard. CEN European Committee for Standarization: Madrid, Spain, 2016 ; p. 11.

29. Goering, H.K.; Van Soest, P.J. Forage Fiber Analyses (Apparatus, Reagents, Procedures and Some Applications); USDA-ARS Agricultural Handbook 379; US Government Printing Office: Washington, DC, USA, 1970; p. 20.

30. EN ISO 18122 (2016); Solid Biofuels. Determination of Ash Content. European Standard. CEN European Committee for Standarization: Madrid, Spain, 2016; 12p.

31. EN ISO 18123 (2016); Solid Biofuels. Determination of the Content of Volatile Matter. European Standard. CEN European Committee for Standarization: Madrid, Spain, 2016; 15p.

32. Rotz, L.; Giazzi, G. Characterization of Pharmaceutical Products by the Thermo Scientific FLASH 2000 Elemental Analyzer; Thermo Fischer Scientific: Milan, Italy, 2012.

33. Arcibar-Orozco, J.; Josue, D.-B.; Rios-Hurtado, J.C.; Rangel-Mendez, J.R. Influence of iron content, surface area and charge distribution in the arsenic removal by activated carbons. Chem. Eng. J. 2014, 249, 201-209. [CrossRef]

34. UNE-EN 15103. Determinación de la Densidad a Granel; Asociación Española de Normalización y Certificación (AENOR): Madrid, España, 2010.

35. Richards, S. Physical testing of fuel briquettes. Fuel Process. Technol. 1990, 25, 89-100. [CrossRef]

36. UNE-EN 14918. Determinación del Poder Calorífico; Asociación Española de Normalización y Certificación (AENOR): Madrid, España, 2010.

37. ISO/TR 19867-3. Clean Cookstoves and Clean Cooking Solutions-Harmonized Laboratory Test Protocols-Part 3: Voluntary Performance Targets for Cookstoves Based on Laboratory Testing; KEBS Centre: Nairobi, Kenya, 2018.

38. Johnson, M.; Edwards, R.; Frenk, C.A.; Masera, O. In-field greenhouse gas emissions from cookstoves in rural Mexican households. Atmos. Environ. 2008, 42, 1206-1222. [CrossRef]

39. Ruiz-García, V.M.; Edwards, R.D.; Ghasemian, M.; Berrueta, V.M.; Princevac, M.; Vázquez, J.C.; Johnson, M.; Masera, O.R. Fugitive Emissions and Health Implications of Plancha-Type Stoves. Environ. Sci. Technol. 2018, 52, 10848-10855. [CrossRef] [PubMed]

40. Rodríguez, R.C.; Brenes-Peralta, L.; Jiménez-Morales, M.F. Evaluación técnica de dos métodos de compostaje para el tratamiento de residuos sólidos biodegradables domiciliarios y su uso en huertas caseras. Rev. Tecnol. Marcha 2016, 29, 25-32. [CrossRef]

41. Vassilev, S.V.; Baxter, D.; Andersen, L.K.; Vassileva, C.G. An overview of the chemical composition of biomass. Fuel 2010, 89, 913-933. [CrossRef]

42. Ivanova, T.; Havrland, B.; Hutla, P.; Muntean, A. Drying of cherry tree chips in the experimental biomass dryer with solar collector. Res. Agric. Eng. 2012, 58, 16-23. [CrossRef]

43. Fengel, D.; Wegener, G. Wood-Chemistry, Ultrastructure, Reactions; Walter de Gruyter: Berlin, Germany, 1983.

44. ISO 17225-2; Solid Biofuels-Fuel Specifications and Clases-Part 2: Graded Wood Pellets. SIS: Stockholm, Sweden, 2014.

45. Rutiaga-Quiñones, J.G.; Pintor-Ibarra, L.F.; Orihuela-Equihua, R.; González-Ortega, N.; Ramírez-Ramírez, M.A.; Carillo-Parra, A.; Carrillo-Ávila, N.; Navarrete-García, M.A.; Ruíz-Aquino, F.; Rangel-Méndez, J.R.; et al. Characterization of Mexican waste biomass relative to energy generation. BioResources 2020, 15, 8529-8553. [CrossRef]

46. Vassileva, C. Contents, modes of occurrence and origin of chlorine and bromine in coal. Fuel 2000, 79, 903-921. [CrossRef]

47. Vassilev, S.V.; Vassileva, C.G. A new approach for the combined chemical and mineral classification of the inorganic matter in coal. 1. Chemical and mineral classification systems. Fuel 2009, 88, 235-245. [CrossRef]

48. Martínez-Pérez, R.; Pedraza-Bucio, F.E.; Orihuela-Equihua, R.; López-Albarrán, P.; Rutiaga-Quiñones, J.G. Calorific value and inorganic material of ten Mexican wood species. Wood Res. 2015, 60, 281-292.

49. Ngangyo-Heya, M.; Foroughbahchk-Pournavab, R.; Carrillo-Parra, A.; Rutiaga-Quiñones, J.G.; Zelinski, V.; Pintor-Ibarra, L.F. Calorific Value and Chemical Composition of Five Semi-Arid Mexican Tree Species. Forests 2016, 7, 58. [CrossRef]

50. Pintor-Ibarra, L.F.; Carrillo-Parra, A.; Herrera-Bucio, R.; López-Albarrán, P.; Rutiaga-Quiñones, J.G. Physical and chemical properties of timber by-products from Pinus leiophylla, P. montezumae and P. pseudostrobus for a bioenergetic use. Wood Res. 2017, $62,849-861$.

51. Cárdenas-Gutiérrez, M.A.; Correa-Méndez, F.; Pedraza-Bucio, F.E.; Carrillo-Parra, A.; Herrera-Bucio, R.; López-Albarrán, P.; Rutiaga-Quiñones, J.G. Chemical components of the branches of six hardwood species. Wood Res. 2018, 63, 795-808.

52. Ruiz-Aquino, F.; Ruiz-Ángel, S.; Feria-Reyes, R.; Santiago-García, W.; Rutiaga-Quiñones, J.G. Wood chemical composition of five tree species from Oaxaca, Mexico. BioResources 2019, 14, 9826-9839. [CrossRef]

53. UNE-EN 14961-1. Especificaciones y Clases de Combustibles. Parte 1: Requisitos Generales; Asociación Española de Normalización y Certificación (AENOR): Madrid, España, 2011.

54. Obernberger, I.; Thek, G. Physical characterisation and chemical composition of densified biomass fuels with regard to their combustion behaviour. Biomass Bioenergy 2004, 27, 653-669. [CrossRef]

55. Van Lith, S.C.; Alonso-Ramírez, V.; Jensen, P.A.; Frandsen, F.J.; Glarborg, P. Release to the Gas Phase of Inorganic Elements during Wood Combustion. Part 1: Development and Evaluation of Quantification Methods. Energy Fuels 2006, 20, 964-978. [CrossRef]

56. Obernberger, I.; Thek, G. The Pellets Handbook: The Production and Thermal Utilization of Biomass Pellets; Earthscan: Abingdon, UK, 2010. 
57. Werkelin, J.; Lindberg, D.; Boström, D.; Skrifvars, B.-J.; Hupa, M. Ash-forming elements in four Scandinavian wood species part 3: Combustion of five spruce samples. Biomass Bioenergy 2011, 35, 725-733. [CrossRef]

58. Kumar, M.; Sabbarwal, S.; Mishra, P.; Upadhyay, S. Thermal degradation kinetics of sugarcane leaves (Saccharum officinarum L.) using thermo-gravimetric and differential scanning calorimetric studies. Bioresour. Technol. 2019, 279, 262-270. [CrossRef]

59. Gašparovič, L.; Koreňová, Z.; Jelemenský, L. Kinetic study of wood chips decomposition by TGA. Chem. Pap. 2010, 64, 174-181. [CrossRef]

60. Setter, C.; Silva, F.; Assis, M.; Ataíde, C.; Trugilho, P.; Oliveira, T. Slow pyrolysis of coffee husk briquettes: Characterization of the solid and liquid fractions. Fuel 2019, 261, 116420. [CrossRef]

61. Flores, J.J.A.; Quiñones, J.G.R.; Rodríguez, M.L.; Vera, J.V.A.; Valencia, J.E.; Martínez, S.J.G.; Montesino, F.M.; Rosas, A.A. Thermal Degradation Kinetics and FT-IR Analysis on the Pyrolysis of Pinus pseudostrobus, Pinus leiophylla and Pinus montezumae as Forest Waste in Western Mexico. Energies 2020, 13, 969. [CrossRef]

62. Koppejan, J.; Van Loo, S. The Handbook of Biomass Combustion and Co-Firing; Earthscan: London, UK, 2012.

63. Tumuluru, J.S.; Sokhansanj, S.; Lim, C.J.; Bi, T.; Lau, A.; Melin, S.; Sowlati, T.; Oveisi, E. Quality of Wood Pellets Produced in British Columbia for Export. Appl. Eng. Agric. 2010, 26, 1013-1020. [CrossRef]

64. Artemio, C.P.; Maginot, N.H.; Serafín, C.-U.; Rahim, F.P.; Guadalupe, R.Q.J.; Fermín, C.-M. Physical, mechanical and energy characterization of wood pellets obtained from three common tropical species. PeerJ 2018, 6, e5504. [CrossRef] [PubMed]

65. Núñez-Retana, V.D.; Escobedo-Bretado, M.A.; Ruiz-Aquino, F.; Quiñones-Reveles, M.; Carrillo-Parra, A. Efecto del contenido de humedad sobre pellets de aserrín de madera de Pinus spp. Rev. Mex. Agrosistemas 2019, 6, 136-144.

66. Camps, M.M.; Marcos, M.F. Los Biocombustibles; Ediciones Mundi-Prensa: Madrid, Spain, 2008.

67. DIN 51731. Test of Solid Fuels—Compressed Untreated Wood-Requeriments and Testing; German Institut for Standarization, Beuth Verlag: Berlin, UK, 1996.

68. Núñez-Retana, V.D.; Wehenkel, C.; Vega-Nieva, D.J.; García-Quezada, J.; Carrillo-Parra, A.; Retana, N.; Nieva, V.; Quezada, G.; Parra, C. The Bioenergetic Potential of Four Oak Species from Northeastern Mexico. Forests 2019, 10, 869. [CrossRef]

69. Bala-Litwiniak, A.; Radomiak, H. Possibility of the Utilization of Waste Glycerol as an Addition to Wood Pellets. Waste Biomass Valorization 2019, 10, 2193-2199. [CrossRef]

70. Obernberger, I.; Thek, G. Recent developments concerning pellet combustion technologies-A review of Austrian developments. In Proceedings of the 2nd World Conference on Pellets, Swedish Bioenergy Association, Jönköpping, Sweden, 30 May-1 June 2006.

71. Peng, J.; Wang, J.; Bi, X.T.; Lim, C.J.; Sokhansanj, S.; Peng, H.; Jia, D. Effects of thermal treatment on energy density and hardness of torrefied wood pellets. Fuel Process. Technol. 2015, 129, 168-173. [CrossRef]

72. Garcia, D.P.; Caraschi, J.C.; Ventorim, G.; Vieira, F.H.A.; Protásio, T.D.P. Comparative Energy Properties of Torrefied Pellets in Relation to Pine and Elephant Grass Pellets. BioResources 2018, 13, 2898-2906. [CrossRef]

73. Peng, J.; Bi, X.T.; Lim, C.J.; Peng, H.; Kim, C.S.; Jia, D.; Zuo, H. Sawdust as an effective binder for making torrefied pellets. Appl. Energy 2015, 157, 491-498. [CrossRef]

74. Tumuluru, J.S.; Sokhansanj, S.; Hess, J.R.; Wright, C.; Boardman, R.D. Review: A review on biomass torrefaction process and product properties for energy applications. Ind. Biotechnol. 2011, 7, 384-401. [CrossRef]

75. Liu, Z.; Quek, A.; Balasubramanian, R. Preparation and characterization of fuel pellets from woody biomass, agro-residues and their corresponding hydrochars. Appl. Energy 2014, 113, 1315-1322. [CrossRef]

76. WHO. WHO Guidelines for Indoor Air Quality: Household Fuel Combustion; World Health Organization: Geneva, Switzerland, 2014; Available online: https:/ /apps.who.int/iris/handle/10665/141496 (accessed on 14 May 2021).

77. Quiñones-Reveles, M.; Ruiz-García, V.; Ramos-Vargas, S.; Vargas-Larreta, B.; Masera-Cerutti, O.; Ngangyo-Heya, M.; CarrilloParra, A. Assessment of Pellets from Three Forest Species: From Raw Material to End Use. Forests 2021, 12, 447. [CrossRef]

78. Thompson, R.J.; Li, J.; Weyant, C.L.; Edwards, R.; Lan, Q.; Rothman, N.; Hu, W.; Dang, J.; Dang, A.; Smith, K.R.; et al. Field Emission Measurements of Solid Fuel Stoves in Yunnan, China Demonstrate Dominant Causes of Uncertainty in Household Emission Inventories. Environ. Sci. Technol. 2019, 53, 3323-3330. [CrossRef] [PubMed] 